\title{
Distribution of Antimicrobial Resistant Genes in Acinetobacter calcoaceticus-baumannii Complex Isolated from Clinical Specimens in Chungcheong, Korea
}

Ji Youn Sung

Department of Biomedical Laboratory Science, Far East University, Eumseong, Korea

\section{충청지역의 임상검체로부터 분리된 Acinetobacter calcoaceticus-baumannii Complex를 대상으로 항균제 내성 유전자 비교분석}

성지연

Species that belong to the Acinetobacter calcoaceticus-baumannii(Acb) complex are major causes of hospital-acquired infections. They are important opportunistic pathogens. These species are usually multidrug resistant (MDR), and the therapeutic options to treat the infections caused by these species are limited. In the present study, we investigated fluoroquinolone resistance mechanisms in 53 ciprofloxacin resistant Acinetobacter species isolates in Chungcheong, Korea. Antimicrobial susceptibilities were determined using the disk-diffusion method. Detections of genes and identification of mutations associated with fluoroquinolone resistance were carried out using PCR and DNA sequencing. In our study, 47 out of 53 ciprofloxacin resistant Acinetobacter isolates harbored sense mutations at the 83rd residue (serine to leucine) in the gyrA gene as well as at the 80th residue (serine to leucine) in the parC gene. Among the 47 isolates harboring sense mutations in gyrA and parC gene, 44 isolates were $A$. baumannii and 3 isolates were $A$. pittii. Plasmid-mediated quinolone resistance (PMQR) determinants were detected in isolates in our study. Among the 46 ciprofloxacin resistant $A$. baumannii isolates, 41 showed type $\mathrm{A}, \mathrm{B}$, or $\mathrm{F}$ banding patterns on their REP-PCR profiles. This result suggests that clonal relation and horizontal spreading of the bacterial isolates have been around hospitals in Chungcheong area. To prevent colonization and disseminations of fluoroquinolone resistance Acb complex isolates, continuous investigation and monitoring of antimicrobial resistant determinants of MDR isolates are needed.

Key words: Acinetobacter calcoaceticus-baumannii complex, A. baumannii, Fluoroquinolone, Multidrug resistant

This is an Open Access article distributed under the terms of the Creative Commons Attribution Non-Commercial License (http://creativecommons.org/licenses/by-nc/4.0) which permits unrestricted non-commercial use, distribution, and reproduction in any medium, provided the original work is properly cited.

Copyright @ 2017 The Korean Society for Clinical Laboratory Science. All rights reserved.
Corresponding author: Ji Youn Sung Department of Biomedical Laboratory Science, Far East University, 76-32 Daehak-gil, Gamgok-myeon, Eumseong 27601, Korea Tel: 82-43-879-3668

Fax: 82-43-880-3876

E-mail: azaza72@naver.com

Received: September 6, 2017 Revised $1^{\text {st: }}$ September 29, 2017 Revised $2^{\text {nd }}:$ September 29, 2017 Revised 3 ${ }^{\text {rd: }}$ : October 11, 2017 Accepted: October 11, 2017 


\section{서 론}

Acinetobacter속에 속한 균종들은 토양과 담수 등 자연환경 에 널리 서식하는 그람음성 막대균으로 이 속에 속한 일부 종들 은 병원감염 및 기회감염의 원인균으로 작용한다. Acinetobacter calcoaceticus-baumannii (Acb) complex에 속하는 $A$. baumannii, A. pittii, 그리고 A. nosocomialis는 병원환경 및 입원환자에서 가장 빈번하게 분리되고 있는 균종으로, 특히 신 생아실이나 중환자실 등에서 유행하며 폐렴, 요로감염, 균혈증 및 심내막염 등 다양한 감염병을 일으키고 있다[1-3]. 이 세균들 에 의한 감염병은 유병율과 치사율이 높은 것으로 알려져 있는 데 최근 여러 계열의 항균제에 내성을 동시에 나타내는 다제내 성 Acinetobacter 균주의 출현이 빈번해 지고 있어 이 세균들에 의한 감염병 치료가 더욱 어려워지고 있다[1-3].

Fluoroquinolones는 일반적으로 그람양성 세균과 그람음 성 세균에 모두 효과적인 광범위 항균제로 cephalosporins 및 aminoglycosides 계열 항균제와 비교해 우수한 항균력을 가지 고 있어 Acinetobacter종들에 의한 감염병 치료를 위해 오래동 안 사용되어왔다. 그러나 최근 fluoroquinolone에 내성을 보이 는 Acinetobacter 종들의 출현 및 확산이 세계 여러 나라에서 보고되어 문제가 되고 있다[4]. Acinetobacter속에 속한 종들 은 다양한 기전으로 fluoroquinolones에 내성을 나타내는데 이러한 내성은 세균세포의 염색체 DNA에 돌연변이가 생기거 나 plasmid를 통해 운반되는 내성유전자를 획득함으로써 나타 난다. 세균세포의 염색체 DNA에 돌연변이가 발생하는 경우 중 대표적인 것이 항균제가 작용하는 효소를 암호화하는 유전자의 돌연변이이다. 가장 빈번하게 돌연변이가 발생하는 유전자는 DNA gyrase 효소를 암호화 하는 $g y r A$ 및 $g y r B$ 유전자와 topoisomerase IV 효소를 암호화 하는 parC 및 $\operatorname{parE}$ 유전자이 다. 이 유전자들은 quinolone resistance determining regions (QRDRs)라고 불리우는 영역에 위치하고 있는데 변이된 유전 자에 의해 생산된 효소는 fluoroquinolones과 결합하지 않으 므로 항균제에 내성을 나타내게 된다. 특히 Acinetobacter속 에 속한 종들은 $g y r A$ 와/또는 $\operatorname{parC}$ 유전자에 돌연변이가 있는 경우 대부분 fluoroquinolones에 고도내성을 보이는 것으로 알려져 있다[4].

한편 세균은 plasmid를 통해 다양한 항균제에 내성을 나타낼 수 있게 하는 유전자들을 획득한다. Plasmid를 통해 운반되며 quinolone에 내성을 나타내도록 하는 인자들을 plasmid-mediated quinolone resistance (PMQR) determinants라고 하 는데 이에 해당하는 유전자에는 $q n r, \operatorname{aac}(6)-1 b-c r, q e p A$, $\circ q \times A$ 및 $O q \times B$ 등이 있다. 이 유전자들에 의해 생성된 단백들은 다양한 방법으로 fluoroquinolone 항균제가 세균세포에 작용 하지 못하도록 하여 세균이 fluoroquinolone 항균제에 내성을 갖도록 한다. Onr 단백은 DNA gyrase와 topoisomerase IV 효 소에 fluoroquinolone 항균제가 결합하는 것을 방해하여 fluoroquinolone 항균제의 항균능력을 저하시킨다[5]. AAC(6')-1b-cr 단백은 aminoglycoside acetyltransferase효 소로 fluoroquinolone 항균제를 변형시켜 항균작용을 못하도 록 한다. 또한 QepA와 OqxAB 단백은 유출펌프를 활성화 시켜 fluoroquinolone 항균제를 세균세포 바깥으로 유출시킴으로 써 fluoroquinolone 항균제가 작용 할 수 없도록 한다[6]. $\mathrm{PMQR}$ 에 포함되는 유전자들은 plasmid를 통해 다양한 균종으 로 빠르게 확산 될 수 있어 내성유전자의 확산이라는 면에서는 큰 문제이지만 Acinetobacter속에 속한 종에서는 드물게 보고 되고 있다 $[7,8]$.

최근까지 전세계적으로 Acinetobacter 속에 속한 종들을 대 상으로 내성연구가 많이 진행되었고 보고되고 있으나 주로 $A$. baumannii 균종에만 국한되어 있거나 carbapenem 내성기전 에 초점이 맞춰져 있는 경우가 대부분이었다[3,4]. 국내에서도 Acinetobacter 속에 속한 종들을 대상으로 한 연구는 많으나 [1,9] fluoroquinolone 항균제에 대한 내성연구는 드물다. 본 연구에서는 충청지역에서 분리된 Acb complex에 속하는 균주 를 대상으로 fluoroquinolone 항균제에 대한 내성기전을 조사 하여 종 간의 내성현황 및 내성기전을 비교 분석하였다. 또한 fluoroquinolone 항균제에 내성을 보이는 균주를 대상으로 repetitive extragenic palindromic sequence-based PCR (REP-PCR)을 시행하여 내성 균주간의 클론성을 비교 및 분석 하였다. DNA fingerprinting 방법 중 하나인 REP-PCR 분석법 은 A. baumannii에 의한 병원내감염의 역학적 특성을 밝히는 데 유용하고 신속한 방법으로 알려져 있으며, 역학조사를 위한 참조방법인 pulsed-field gel electrophoresis (PFGE) 방법으 로 얻은 결과와 유사한 결과를 보인다고 보고되고 있다[10]. 본 연구결과는 충청지역에서 분리되는 Acinetobacter 속에 속한 균주들의 내성양상을 파악하는데 도움이 될 것으로 사료된다.

\section{재료 및 방법}

\section{1. 균주의 수집 및 균종 동정}

본 연구는 수집기간인 2014년 8월부터 2016월 5월까지 충 청지역에 위치한 대학병원에 의뢰된 객담(68), 소변(18), 기관 지세척액(14) 및 그 외 검체(4)로부터 분리된 104균주의 Acb 
complex에 속하는 Acinetobacter species를 대상으로 하였 다. 동일 환자에서 반복 분리된 균주는 수집대상에서 제외하였 다. 검체로부터 분리배양된 균주를 대상으로 Vitek $2 \mathbb{R}$ automated instrument ID system (bioMérieux, Marcy l'Etoile, France)을 이용하여 일차 균종 동정을 하였다. Vitek 2R automated instrument ID system (bioMérieux) 분석결 과가 Acinetobacter속에 속한 종인 균주를 대상으로 최종 균종 동정을 위해 Ac1055F (5'-GTGATAARATGGCBGGTCGT-3') 및 Ac1598R (5'-CGBGCRTGCATYTTGTCRT-3')를 시발체 로 $r p o B$ 유전자를 증폭시켜 염기서열을 분석하였다[2]. 먼저 대 상 균주를 brain heart infusion broth (Difco, Cockeysville, $\mathrm{MD}$, $\mathrm{USA}$ )에 접종하여 $37^{\circ} \mathrm{C}$ 에서 24 시간 배양한 후 배양액으로 부터 DNA purification kit (Bioneer, Daejeon, Korea)을 사용 하여 DNA를 추출하였다. AccuPower PCR PreMix (Bioneer) 에 DNA 추출액 $(2.5 \mu \mathrm{L})$, primer 각 $10 \mathrm{pmol}$ 및 증류수를 혼합 하여 총 부피 $25 \mu \mathrm{L}$ 의 반응용액을 만들었다. GenePro Thermal Cycler B48D (Bioer Technology Corp. Ltd, China)로 $95^{\circ} \mathrm{C}$ 에서 5 분간 반응시킨 후, $95^{\circ} \mathrm{C}$ 에서 30 초, $52^{\circ} \mathrm{C}$ 에서 40 초, $72^{\circ} \mathrm{C}$ 에서 30 초씩 30 회 증폭 반응시키고, $72^{\circ} \mathrm{C}$ 에서 5 분간 연 장 반응시켰다. 각각의 PCR 반응산물을 ethidium bromide가 포함된 1.5\% agarose gel에서 30분간 전기영동하여 밴드를 확 인하였다. 증폭산물을 PCR purification kit (Bioneer)로 분리 후, BigDye Terminator Cycle Sequencing Kit (PE Applied Biosystems, Foster City, CA, USA)와 ABI PRISM 3730xl DNA analyzer (PE Applied Biosystems)를 이용하여 염기 서
열을 분석하였다.

\section{2. 항균제 감수성 시험}

Mueller-Hinton 한천배지(Difco)를 사용하여 amikacin, gentamicin, aztreonam, cefepime, ceftazidime, ciprofloxacin, imipenem 및 meropenem (BBL, Cockeysville, MI, USA)에 대한 감수성을 Clinical and Laboratory Standards Institute (CLSI) 지침에 따라 디스크 확산법으로 확인하였다 [11]. 정도관리를 위해 Escherichia coli ATCC 25922와 Pseudomonas aeruginosa ATCC 27853을 동시에 시험하여 허용범위내에 있는지 확인하였다.

본 연구에서는 Acinetobacterspecies가 aminoglycosides, carbapenems, 광범위 cephalosporins 및 quinolones 계열의 항균제 중 3계열 이상의 항균제에 내성을 나타낼 경우 다제내성 (multidrug-resistant, MDR) Acinetobacter species로 정하 였다[3].

\section{Quinolone 내성인자 검출}

$\mathrm{QRDR}$ 에 위치한 $g y r A$ 및 $\operatorname{parC}$ 유전자의 돌연변이와 $\mathrm{PMQR}$ determinants를 검출하기 위해 기존의 시발체(Table 1)를 사용 하여 중합효소연쇄반응을 수행하였다[12-15]. 균종 동정을 위 해 $r p o B$ 유전자를 증폭시킬 때와 동일한 방법으로 준비한 DNA 추출액 $(2.5 \mu \mathrm{L})$, primer 각 $10 \mathrm{pmol}$, AccuPower PCR PreMix (Bioneer) 및 증류수를 혼합하여 총 부피 $25 \mu \mathrm{L}$ 의 반응용액을 만들었다. GenePro Thermal Cycler B48D (Bioer Technology

Table 1. Oligonucleotides used in this study for detection of quinolone resistance determinants

\begin{tabular}{|c|c|c|c|}
\hline Primer & Sequence $\left(5^{\prime}-3^{\prime}\right)$ & Gene & Reference \\
\hline \multicolumn{4}{|c|}{ QRDR mutation detection } \\
\hline gyrA-F & AAATCTGCTCGTGTCGTTGG & gyrA & [12] \\
\hline gyrA-R & GCCATACCTACAGCAATACC & & \\
\hline parC-F & AAGCCCGTACAGCGCCGTATT & parc & [12] \\
\hline $\operatorname{parC}-\mathrm{R}$ & AAAGTTATCTTGCCATTCGCT & & \\
\hline \multicolumn{4}{|c|}{ PMQR gene detection } \\
\hline QnrA-F & AGAGGATTTCTCACGCCAGG & qnrA & [13] \\
\hline QnrA-R & TGCCAGGCACAGATCTTGAC & & \\
\hline QnrB-F & GGMATHGAAATTCGCCACTG & $q n r B$ & [13] \\
\hline QnrB-R & TTTGCYGYYCGCCAGTCGAA & & \\
\hline QnrS-F & GCAAGTTCATTGAACAGGGT & qnrs & [13] \\
\hline QnrS-R & TCTAAACCGTCGAGTTCGGCG & & \\
\hline $\operatorname{Aac}(6)-I b-F$ & TTGCGATGCTCTATGAGTGGCTA & $\operatorname{aac}(6)-1 b-c r$ & [14] \\
\hline$A a c(6)-I b-R$ & CTCGAATGCCTGGCGTGTTT & & \\
\hline QepA-F & CCAGCTCGGCAACTTGATAC & qepA & [15] \\
\hline QepA-R & ATGCTCGCCTTCCAGAAAA & & \\
\hline OqxA-F & CTCGGCGCGATGATGCT & $o q \times A$ & [15] \\
\hline OqxA-R & CCACTCTTCACGGGAGACGA & & \\
\hline
\end{tabular}

Abbreviations: $F$, sense primer; $R$, antisense primer; $M, A / C ; H, A / T / C ; Y, C / T$. 
Corp.)로 $95^{\circ} \mathrm{C}$ 에서 5 분간 반응시킨 후, $94^{\circ} \mathrm{C}$ 에서 30 초, $56^{\circ} \mathrm{C}$ 에서 30 초, $72^{\circ} \mathrm{C}$ 에서 50 초씩 30 회 증폭 반응시키고, $72^{\circ} \mathrm{C}$ 에서 5 분간 연장 반응시켰다. 중합효소연쇄반응에서 생성된 반응산 물을 ethidium bromide가 포함된 1.5\% agarose gel에서 30분 간 전기영동하여 band를 확인한 후 $r p o B$ 유전자 분석할 때와 동일한 방법으로 염기서열분석을 시행하였다.

\section{REP-PCR을 이용한 ciprofloxacin 내성 $A$. baumannii의 역학적 연관성 조사}

시발체로는 REP1 (5'-IIIGCGCCGICATCAGGC-3')과 REP2 (5'-ACGTCTTATCAGGCCTAC-3') 로 명명된 장내세균의 반 복 서열을 이용하였다[10]. 증폭반응은 DNA 추출액 $(5.0 \mu \mathrm{L})$, primer 각 20 pmol, AccuPower PCR PreMix (Bioneer) 및 증 류수를 혼합하여 총 부피 $50 \mu \mathrm{L}$ 의 반응용액을 만들었다. GenePro Thermal Cycler B48D (Bioer Technology Corp.) 로 $95^{\circ} \mathrm{C}$ 에서 5 분간 반응시킨 후, $90^{\circ} \mathrm{C}$ 에서 40 초, $42^{\circ} \mathrm{C}$ 에서 1 분, $68^{\circ} \mathrm{C}$ 에서 7 분씩 35 회 증폭 반응시키고, $68^{\circ} \mathrm{C}$ 에서 15 분간 연장 반응시켰다. 증폭산물 $(10 \mu \mathrm{L})$ 을 ethidium bromide가 포 함된 2\% agarose gels에 전기영동 한 후 Slite 140 Image System (Novusci, Bedfordshire, UK)을 이용하여 band패턴 을 분석하였다. Band의 강도와 상관없이 band의 개수 및 분자 량으로 각 균주를 비교하였으며, 두 개 이상의 밴드 차이가 있으 면 역학적 상관관계가 없는 것으로 판단하였다[10].

\section{결 과}

\section{Ciprofloxacin 내성 Acinetobacter species의 분리}

수집기간동안 총 104 균주의 Acb complex에 속하는 Acinetobacter species가 분리되었는데 A. baumannii가 56 균주로 가장 많았으며 A. pittii가 28균주로 그 다음으로 많았고 A. nosocomialis는 20균주가 분리되었다. 한편 임상검체 종류 에 따라 균종의 분리빈도가 다르게 나타났는데 객담 검체에서 는 A. baumannii 가(46/68) 압도적으로 많이 분리되었으며 그 다음으로 A. pittii 가(16/68) 많이 분리되었다. 반면 소변 검체 에서는 A. pittii가(8/18) 가장 빈번하게 분리되었으며 그 다음 으로 A. nosocomialis 가(6/18) 많이 분리되었다. 기관지세척 액 검체에서는 Acb complex에 속하는 Acinetobacterspecies 가 모두 유사한 빈도로 분리되었다.

이 균주들을 대상으로 ciprofloxacin에 대한 항균제 감수성 시험을 한 결과 총 53균주 즉 46균주(82.1\%)의 A. baumannii, 4균주(14.3\%)의 A. pittii, 그리고 3균주(15.0\%)의 A. no- socomialis 가 ciprofloxacin에 내성을 가지고 있는 것이 확인 되었다(Table 2). 또한 시험기간 동안 분리된 총 53 균주의 ciprofloxacin 내성 Acinetobacterspecies 중 49균주가 다제 내성을 보였다. 한편 정도관리를 위해 E. coli ATCC 25922와 $P$. aeruginosa ATCC 27853 균주도 Acinetobacterspecies와 동 일한 방법으로 9종류의 항균제에 대해 감수성 검사를 시행하였 다. 그 결과 E. coli ATCC 25922의 항균제 억제영역의 직경 (mm)은 각각 amikacin (23), gentamicin (24), aztreonam (32), cefepime (35), ceftazidime (31), ciprofloxacin (36), imipenem (30) 및 meropenem (32)인 것으로 나타나 모두 허 용범위내에 들었다. P. aeruginosa ATCC 27853 또한 각 항균 제에 대해 억제영역의 직경 $(\mathrm{mm})$ 이 amikacin (24), gentamicin (20), aztreonam (26), cefepime (28), ceftazidime (26), ciprofloxacin (30), imipenem (26) 및 meropenem (32)로 모 두 허용범위내에 드는 것으로 나타났다.

\section{Quinolone 내성인자 검출 및 분석}

총 53균주의 ciprofloxacin 내성 Acinetobacter species를 대상으로 $g y r A$ 및 $\operatorname{par} C$ 유전자에 돌연변이가 있는지를 확인하 기 위해 중합효소연쇄반응과 염기서열분석을 수행한 결과 $A$. baumannii 44균주, A. pittii 3균주, 그리고 A. nosocomialis 한 균주로 구성된 총 48균주가 $g y r A$ 와/또는 $\operatorname{parC}$ 유전자에 돌 연변이를 가지고 있었다(Table 2). 돌연변이가 확인된 48균주 의 Acinetobacterspecies중 A. nosocomialis 한 균주를 제외 한 나머지 47 균주는 $g y r A$ 와 $\operatorname{par} C$ 유전자 모두에 돌연변이를 가지고 있었다. 본 연구에서 확인된 $g y r A$ 및 $\operatorname{parC}$ 유전자 돌연 변이는 염기의 치환에 의해 serine 잔기가 leucine 잔기로 치환 되는 sense mutation으로 gyrA 유전자의 83번째 아미노산 (serine)과 parC 유전자의 80번째 아미노산(serine)이 leucine 으로 치환된 돌연변이였다.

한편 본 연구에서는 53균주의 ciprofloxacin 내성 Acinetobacter species를 대상으로 PMQR 유전자인 $q n r$, $\operatorname{aac}(6)-1 b-c r, q e p A$ 및 $o q X A$ 유전자의 빈도를 조사하기 위해 중합효소연쇄반응을 시행하였으나 양성반응을 보인 균주는 하 나도 없는 것으로 나타났다.

\section{Ciprofloxacin 내성 $A$. baumannii의 유전형 분석}

시험기간 중 분리된 46균주의 ciprofloxacin 내성 $A$. baumannii가 같은 클론에서 유래되었는지를 확인하기 위하여 REP-PCR을 수행한 결과 총 7개의 band 패턴(A, B, C, D, E, F 및 $\mathrm{G}$ 형)이 확인되었다(Figure 1). 분석대상이 되었던 46 균주 
Table 2. Antimicrobial susceptibility patterns and characteristics of 53 Acinetobacter spp. isolated from clinical specimens in Chungcheong, Korea

\begin{tabular}{|c|c|c|c|c|c|c|c|c|c|c|c|c|}
\hline \multirow{2}{*}{ Isolate } & \multirow{2}{*}{ Acinetobacter spp. } & \multicolumn{8}{|c|}{ Antimicrobial susceptibility } & \multicolumn{2}{|c|}{$\mathrm{QRDR}^{*}$ mutations in } & \multirow{2}{*}{$\begin{array}{r}\mathrm{PMQR}^{\dagger} \\
\text { genes }\end{array}$} \\
\hline & & AMK & GEN & AZT & FEP & CAZ & CIP & IPM & MEM & gyrA & parc & \\
\hline R401 & A. baumannii & $R$ & $\mathrm{R}$ & $R$ & $\mathrm{R}$ & $\mathrm{R}$ & $R$ & $\mathrm{R}$ & $R$ & Ser83Leu & Ser83Leu & - \\
\hline R402 & A. baumannii & R & $R$ & $\mathrm{R}$ & $\mathrm{R}$ & $\mathrm{R}$ & $R$ & $R$ & R & Ser83Leu & Ser83Leu & - \\
\hline R403 & A. baumannii & R & $R$ & $\mathrm{R}$ & $\mathrm{R}$ & $\mathrm{R}$ & $R$ & $\mathrm{R}$ & $\mathrm{R}$ & Ser83Leu & Ser83Leu & - \\
\hline R404 & A. baumannii & R & $R$ & $\mathrm{R}$ & $\mathrm{R}$ & $\mathrm{R}$ & $R$ & $R$ & R & Ser83Leu & Ser83Leu & - \\
\hline R405 & A. baumannii & R & $R$ & $\mathrm{R}$ & $R$ & $\mathrm{R}$ & $R$ & $R$ & R & - & - & - \\
\hline R406 & A. baumannii & R & $R$ & R & R & $\mathrm{R}$ & $R$ & $R$ & R & Ser83Leu & Ser83Leu & - \\
\hline R407 & A. baumannii & R & $R$ & $\mathrm{R}$ & $R$ & $\mathrm{R}$ & $R$ & R & R & Ser83Leu & Ser83Leu & - \\
\hline R409 & A. baumannii & R & $R$ & $\mathrm{R}$ & $R$ & $\mathrm{R}$ & $R$ & R & R & Ser83Leu & Ser83Leu & - \\
\hline R410 & A. baumannii & R & $\mathrm{R}$ & R & $R$ & $\mathrm{R}$ & $\mathrm{R}$ & R & R & Ser83Leu & Ser83Leu & - \\
\hline R501 & A. baumannii & R & $\mathrm{R}$ & R & $\mathrm{R}$ & $\mathrm{R}$ & $\mathrm{R}$ & R & R & Ser83Leu & Ser83Leu & - \\
\hline R502 & A. baumannii & S & I & R & $\mathrm{R}$ & $\mathrm{R}$ & $\mathrm{R}$ & R & R & Ser83Leu & Ser83Leu & - \\
\hline R503 & A. baumannii & R & $\mathrm{R}$ & R & $\mathrm{R}$ & $\mathrm{R}$ & $\mathrm{R}$ & R & R & Ser83Leu & Ser83Leu & - \\
\hline R504 & A. baumannii & S & $\mathrm{R}$ & R & $\mathrm{R}$ & $\mathrm{R}$ & $\mathrm{R}$ & R & R & Ser83Leu & Ser83Leu & - \\
\hline R505 & A. baumannii & $\mathrm{S}$ & $\mathrm{S}$ & R & $\mathrm{R}$ & $\mathrm{R}$ & $\mathrm{R}$ & R & R & Ser83Leu & Ser83Leu & - \\
\hline R506 & A. baumannii & $\mathrm{S}$ & I & R & $\mathrm{R}$ & $\mathrm{R}$ & $\mathrm{R}$ & R & R & Ser83Leu & Ser83Leu & - \\
\hline R507 & A. baumannii & $\mathrm{S}$ & $\mathrm{S}$ & R & $\mathrm{R}$ & $\mathrm{R}$ & $\mathrm{R}$ & $\mathrm{S}$ & S & Ser83Leu & Ser83Leu & - \\
\hline R508 & A. baumannii & R & $\mathrm{R}$ & R & $\mathrm{R}$ & $\mathrm{R}$ & $\mathrm{R}$ & $\mathrm{R}$ & R & Ser83Leu & Ser83Leu & - \\
\hline R509 & A. baumannii & R & $\mathrm{R}$ & $\mathrm{R}$ & $\mathrm{R}$ & $\mathrm{R}$ & $\mathrm{R}$ & $\mathrm{R}$ & R & Ser83Leu & Ser83Leu & - \\
\hline R510 & A. baumannii & R & $\mathrm{R}$ & R & $\mathrm{R}$ & $\mathrm{R}$ & $\mathrm{R}$ & $\mathrm{R}$ & R & Ser83Leu & Ser83Leu & - \\
\hline R511 & A. baumannii & R & $\mathrm{R}$ & $\mathrm{R}$ & $\mathrm{R}$ & $\mathrm{R}$ & $\mathrm{R}$ & $\mathrm{R}$ & R & Ser83Leu & Ser83Leu & - \\
\hline R512 & A. baumannii & S & S & $\mathrm{R}$ & $\mathrm{R}$ & $\mathrm{R}$ & $\mathrm{R}$ & I & i & Ser83Leu & Ser83Leu & - \\
\hline R601 & A. baumannii & R & $\mathrm{R}$ & $\mathrm{R}$ & $\mathrm{R}$ & $\mathrm{R}$ & $\mathrm{R}$ & $\mathrm{R}$ & R & Ser83Leu & Ser83Leu & - \\
\hline R602 & A. baumannii & R & $\mathrm{R}$ & $\mathrm{R}$ & $\mathrm{R}$ & $\mathrm{R}$ & $\mathrm{R}$ & $\mathrm{R}$ & R & - & - & - \\
\hline R603 & A. baumannii & R & $\mathrm{R}$ & $\mathrm{R}$ & $\mathrm{R}$ & $\mathrm{R}$ & $\mathrm{R}$ & $\mathrm{R}$ & R & Ser83Leu & Ser83Leu & - \\
\hline R604 & A. baumannii & R & $\mathrm{R}$ & $\mathrm{R}$ & $\mathrm{R}$ & $\mathrm{R}$ & $\mathrm{R}$ & $\mathrm{R}$ & R & Ser83Leu & Ser83Leu & - \\
\hline R605 & A. baumannii & $R$ & $\mathrm{R}$ & $\mathrm{R}$ & $\mathrm{R}$ & $\mathrm{R}$ & $\mathrm{R}$ & $\mathrm{R}$ & $R$ & Ser83Leu & Ser83Leu & - \\
\hline R606 & A. baumannii & $\mathrm{R}$ & $\mathrm{R}$ & $\mathrm{R}$ & $\mathrm{R}$ & $\mathrm{R}$ & $\mathrm{R}$ & $\mathrm{R}$ & $\mathrm{R}$ & Ser83Leu & Ser83Leu & - \\
\hline R607 & A. baumannii & $\mathrm{R}$ & $\mathrm{R}$ & $\mathrm{R}$ & $\mathrm{R}$ & $\mathrm{R}$ & $R$ & $\mathrm{R}$ & $R$ & Ser83Leu & Ser83Leu & - \\
\hline R608 & A. baumannii & R & $R$ & $\mathrm{R}$ & $R$ & $R$ & $R$ & R & $R$ & Ser83Leu & Ser83Leu & - \\
\hline R609 & A. baumannii & $R$ & $\mathrm{R}$ & $\mathrm{R}$ & $R$ & $\mathrm{R}$ & $R$ & $\mathrm{R}$ & $R$ & Ser83Leu & Ser83Leu & - \\
\hline R610 & A. baumannii & R & $\mathrm{R}$ & $\mathrm{R}$ & $\mathrm{R}$ & $\mathrm{R}$ & $\mathrm{R}$ & R & $\mathrm{R}$ & Ser83Leu & Ser83Leu & - \\
\hline R611 & A. baumannii & S & $\mathrm{S}$ & $\mathrm{R}$ & i & $\mathrm{R}$ & $R$ & S & i & Ser83Leu & Ser83Leu & - \\
\hline $\mathrm{R} 612$ & A. baumannii & R & $\mathrm{R}$ & R & $\mathrm{R}$ & $\mathrm{R}$ & $\mathrm{R}$ & R & R & Ser83Leu & Ser83Leu & - \\
\hline R613 & A. baumannii & R & $\mathrm{R}$ & $\mathrm{R}$ & $\mathrm{R}$ & $\mathrm{R}$ & $\mathrm{R}$ & R & R & Ser83Leu & Ser83Leu & - \\
\hline R614 & A. baumannii & R & $\mathrm{R}$ & $\mathrm{R}$ & $\mathrm{R}$ & $\mathrm{R}$ & $\mathrm{R}$ & R & R & Ser83Leu & Ser83Leu & - \\
\hline R615 & A. baumannii & R & $\mathrm{R}$ & $\mathrm{R}$ & $\mathrm{R}$ & $\mathrm{R}$ & $\mathrm{R}$ & R & R & Ser83Leu & Ser83Leu & - \\
\hline R616 & A. baumannii & R & $\mathrm{R}$ & R & R & $\mathrm{R}$ & $\mathrm{R}$ & R & $\mathrm{R}$ & Ser83Leu & Ser83Leu & - \\
\hline R617 & A. baumannii & R & $\mathrm{R}$ & $\mathrm{R}$ & R & $\mathrm{R}$ & $\mathrm{R}$ & R & R & Ser83Leu & Ser83Leu & - \\
\hline R618 & A. baumannii & R & $\mathrm{R}$ & R & R & $\mathrm{R}$ & $R$ & R & R & Ser83Leu & Ser83Leu & - \\
\hline R619 & A. baumannii & R & $\mathrm{R}$ & R & $\mathrm{R}$ & $\mathrm{R}$ & $\mathrm{R}$ & $\mathrm{R}$ & $R$ & Ser83Leu & Ser83Leu & - \\
\hline R620 & A. baumannii & R & $\mathrm{R}$ & R & R & $\mathrm{R}$ & $\mathrm{R}$ & $\mathrm{R}$ & $R$ & Ser83Leu & Ser83Leu & - \\
\hline R621 & A. baumannii & R & $\mathrm{R}$ & $\mathrm{R}$ & $\mathrm{R}$ & $\mathrm{R}$ & $R$ & $R$ & $R$ & Ser83Leu & Ser83Leu & - \\
\hline R622 & A. baumannii & R & $\mathrm{R}$ & R & R & $\mathrm{R}$ & $\mathrm{R}$ & $\mathrm{R}$ & $R$ & Ser83Leu & Ser83Leu & - \\
\hline R623 & A. baumannii & S & S & R & $\mathrm{R}$ & $\mathrm{R}$ & $\mathrm{R}$ & $\mathrm{S}$ & S & Ser83Leu & Ser83Leu & - \\
\hline R624 & A. baumannii & $\mathrm{R}$ & $R$ & $R$ & $\mathrm{R}$ & $\mathrm{R}$ & $R$ & $\mathrm{R}$ & $\mathrm{R}$ & Ser83Leu & Ser83Leu & - \\
\hline R625 & A. baumannii & $\mathrm{R}$ & $\mathrm{R}$ & $\mathrm{R}$ & $\mathrm{R}$ & $\mathrm{R}$ & $\mathrm{R}$ & $\mathrm{R}$ & R & Ser83Leu & Ser83Leu & - \\
\hline RP401 & A. pittii & R & $\mathrm{R}$ & $\mathrm{R}$ & $R$ & $\mathrm{R}$ & $R$ & $R$ & $\mathrm{R}$ & herosta & te & - \\
\hline RP402 & A. pittii & $\mathrm{R}$ & $\mathrm{R}$ & $\mathrm{R}$ & $\mathrm{R}$ & $\mathrm{R}$ & $\mathrm{R}$ & $\mathrm{R}$ & R & Ser83Leu & Ser83Leu & - \\
\hline RP403 & A. pittii & $\mathrm{R}$ & $\mathrm{R}$ & $\mathrm{R}$ & $R$ & $\mathrm{R}$ & $\mathrm{R}$ & $\mathrm{R}$ & R & Ser83Leu & Ser83Leu & - \\
\hline RP404 & A. pittii & $\mathrm{R}$ & $\mathrm{R}$ & $\mathrm{R}$ & $\mathrm{R}$ & $R$ & $\mathrm{R}$ & $\mathrm{R}$ & $\mathrm{R}$ & Ser83Leu & Ser83Leu & - \\
\hline SN603 & A nosocomialis & S & $\mathrm{R}$ & $R$ & $\mathrm{~S}$ & S & $\mathrm{R}$ & S & S & - & $\begin{array}{c}- \\
-\end{array}$ & - \\
\hline RN401 & A nosocomialis & $\mathrm{R}$ & $\mathrm{R}$ & $\mathrm{R}$ & $\mathrm{R}$ & $\mathrm{R}$ & $\mathrm{R}$ & $\mathrm{R}$ & R & Ser83Leu & - & - \\
\hline RN402 & A nosocomialis & R & $\mathrm{R}$ & $\mathrm{R}$ & $R$ & $R$ & 4 & R & R & - & - & - \\
\hline
\end{tabular}

$\operatorname{aac}(6)-1 b-c r$, qepA 및 oqxA.

Abbreviations: AMK, amikacin; GEN, gentamicin; AZT, aztreonam; FEP, cefepime; CAZ, ceftazidime; CIP, ciprofloxacin; IPM, imipenem; MEM, meropenem; S, susceptible; I, intermediate resistant; $R$, resistant.

*Point mutations in the quinolone resistance-determining regions (QRDRs). ${ }^{\dagger}$ Plasmid-mediated quinolone resistance (PMQR) genes: qnr, 


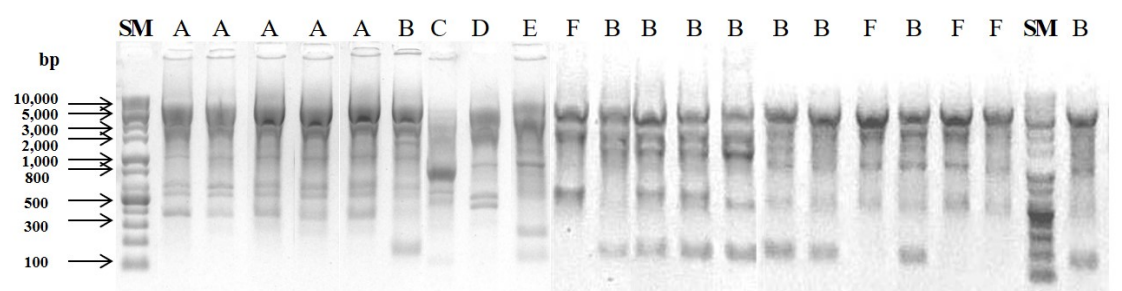

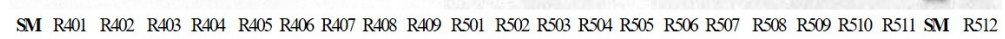

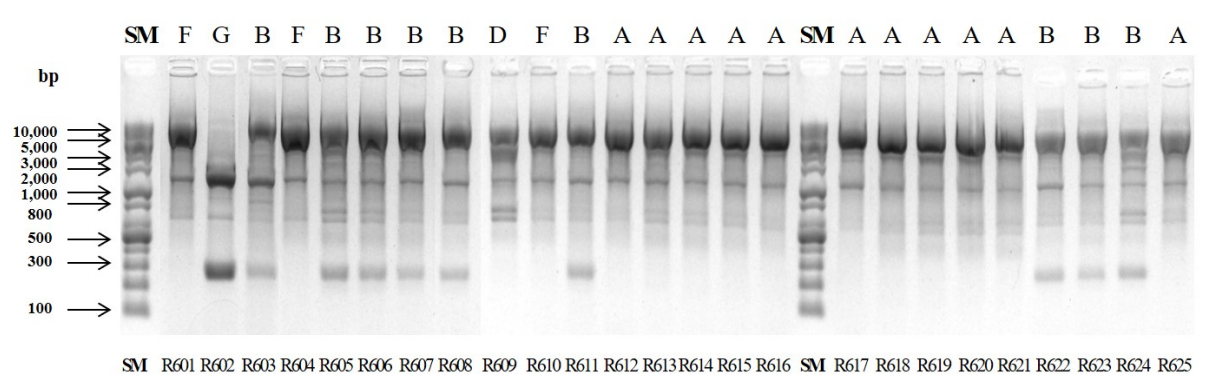

Figure 1. Repetitive element sequence-based (REP)-PCR patterns of genomic DNA from forty-six ciprofloxacin resistant Acinetobacter baumannii isolates. Land SM is $1 \mathrm{~kb}$ DNA size marker.

중 5균주를 제외한 41균주가 A형(16균주), B형(18균주), 또는 F형(7균주)의 band 패턴을 보였다.

\section{고 찰}

Acinetobacter속에 속한 종들은 병원감염 및 기회감염을 일 으키는 주된 원인균으로 다양한 항균제 내성인자를 가지고 있 어 병원환경에서 내성유전자의 확산에 중요한 역할을 한다[2]. 따라서 Acinetobacter 속에 속한 종들을 대상으로 한 항균제 내 성연구는 병원감염관리를 위해 매우 중요하다. 본 연구에서는 환자로부터 분리된 Acb complex에 속하는 균주를 대상으로 항균제 감수성 양상과 fluoroquinolone 항균제에 대한 내성기 전 조사하였으며 Acinetobacter 종간의 차이점을 비교 분석하 였다.

연구기간 동안 총 53 균주의 ciprofloxacin 내성 Acinetobacter species가 임상검체로부터 분리되었는데 그 중 $86.8 \%$ 에 해당하는 46균주가 A. baumannii였다. A. baumannii 균주의 ciprofloxacin에 대한 항균제 내성율은 $82.1 \%$ 로 $A$. pittii 균주(14.3\%)나 A. nosocomialis 균주 (15.0\%)보다 5배 이상 높았는데 이전에 아프리카(82.4\%)와 국내(79.5\%)에서 보 고된 연구결과와 유사한 내성율을 보이고 있다[16,17]. 본 연구 에서 분리된 A. pittii 및 A. nosocomialis 균주들의 ciprofloxacin에 대한 내성율은 $15.0 \%$ 이하로 A. baumannii 균주보 다 매우 낮았는데 유사한 결과(13.3 14.3\%)가 이전에 국내에 서 보고된 바 있다[17]. 이상의 결과에서 Acb complex에 속하 는 Acinetobacter 종들 중 A. baumannii의 분리빈도와 ciprofloxacin에 대한 내성율이 non-A. baumannii에 비해 월
등하게 높은 것으로 나타났는데 이는 Acinetobacter 종들 중주 된 병원감염균으로 작용하고 임상적으로 매우 중요한 종이 $A$. baumannii 임을 의미한다. 이전의 국내외의 많은 연구자들은 역시 Acinetobacter종들 중 A. baumannii 균주가 기회감염 및 병원감염을 일으키는 주된 원인균으로 대부분의 A. baumannii 균주가 다제내성을 나타낸다고 보고하고 있다[17-19].

Acinetobacter species가 fluoroquinolone에 내성을 나타 내는 가장 중요한 기전 중 하나가 DNA gyrase 와 DNA topoisomerase IV의 돌연변이이다. 특이 $\operatorname{gyr} A$ 와 $\operatorname{parC}$ 유전자 에 모두 돌연변이가 일어나 아미노산이 치환될 경우 fluoroquinolone에 고도내성을 나타낸다고 알려져 있다[19]. 본 연 구에서도 수집된 53 균주의 ciprofloxacin 내성 Acinetobacterspecies 중 44균주의 A. baumannili와 3균주의 A. pittii 가 gyrA 와 $\operatorname{parC}$ 유전자 모두에 돌연변이를 가지고 있는 것이 확인되었다. 이들은 종에 상관없이 모두 serine 잔기가 leucine 잔기로 치환되는 sense mutation을 $g y r A$ 유전자와 $\operatorname{par} C$ 유전 자에 포함하고 있었다. 본 연구에서 확인된 serine 잔기의 leucine 잔기로의 치환은 이미 A. baumannii 균주를 대상으로 많은 연구에서 보고된 바 있다[20,21]. 그러나 A. pittii 또는 $A$. nosocomialis 균주를 대상으로 한 연구에서 gyrA와/또는 $\operatorname{par} C$ 유전자에 sense mutation이 있음을 보고한 연구는 그동 안 거의 없었다. 그러나 본 연구에서는 A. pittii 균주 역시 $A$. baumannii 균주와 마찬가지로 gyrA와 parC 유전자 모두에 sense mutation을 가질 경우 fluoroquinolone에 고도내성을 보일 수 있음을 확인하여 의미가 있었다. 한편 본 연구에서 수집 된 53 균주의 ciprofloxacin 내성 Acinetobacter species는 $\mathrm{PMQR}$ 유전자를 포함하고 있지 않았는데 이 결과는 Acine- 
tobacterspecies의 fluoroquinolone 내성과 PMQR 유전자의 획득은 크게 관련성이 없음을 뒷받침 하는 것으로 이전의 Acinetobacter species를 대상으로 한 연구에서도 PMQR 유 전자의 검출빈도가 매우 낮거나 검출되지 않았다고 보고하고 있다[22-24].

본 연구에서는 총 44균주의 ciprofloxacin 내성 $\mathrm{A}$. baumannii가 분리되었는데 이들을 대상으로 서로 같은 clone에서 유래했는지 여부를 알아보기 위해 REP-PCR을 수행한 결과 분 석대상이 되었던 46 균주 중 5균주를 제외한 41균주가 A형, B 형, 또는 F형 band 패턴을 보였다. 이러한 결과는 ciprofloxacin 내성 A. baumannii 균주들이 병원내에서 수평확산 되었음을 의미한다.

Ciprofloxacin 내성 Acb complex에 속한 균주의 분리빈도 가 지속적으로 증가하고 있음에도 불구하고 충청지역에서 분리 된 Acinetobacter 균주의 항균제 감수성 양상 및 fluoroquinolone 내성기전에 대한 연구는 상대적으로 많지 않았 다. 본 연구에서는 충청지역에서 분리된 Acb complex에 속한 균주를 대상으로 항균제 감수성 양상과 fluoroquinolone 내성 기전을 분석하였는데 A. baumannii가 다른 Acinetobacter종 들에 비해 항균제 내성율이 높고 다제내성을 나타낼 가능성이 많은 것으로 나타났다. 또 Acinetobacter species의 fluoroquinolone에 대한 내성은 $\mathrm{PMQR}$ 유전자의 획득 보다는 $\operatorname{gyr} A$ 및 $\operatorname{par} C$ 유전자의 돌연변이 획득이 더 크게 관련성이 있는 것으로 나타났다. 한편 다제내성 A. baumannii 균주가 병원환 경에 지속적으로 확산되고 있음이 확인되었는데 이를 방지하게 위해서는 지속적으로 항균제 내성을 유발하는 인자를 조사하고 내성세균의 변화 및 확산 양상을 감시해야 할 것으로 사료된다

\section{요 약}

Acinetobacter calcoaceticus-baumannii (Acb) complex 에 속한 종들은 빈번하게 병원감염 및 기회감염을 일으킨다. 또 한 다제내성인 경우가 많아 이 균들의 감염증 치료를 위한 항균 제 선택이 매우 제한적이다. 본 연구에서는 ciprofloxacin 내성 Acinetobacterspecies 53균주를 대상으로 fluoroquinolone 내성기전을 조사했다. 항균제 감수성 양상을 조사하기 위해 디 스크확산법이 시행되었다. Fluoroquinolone 내성과 관련된 유 전자 및 돌연변이 검출을 위해 PCR과 염기서열분석이 이루어 졌다. 본 연구에서 수집된 53균주의 ciprofloxacin 내성 Acinetobacter 중 47균주가 gyrA 유전자의 83번째 serine 아 미노산 잔기와 $\operatorname{parC}$ 유전자의 80 번째 serine 아미노산 잔기가 leucine 잔기로 치환된 sense mutations 가지고 있는 것으로 나타났다. $g y r A$ 와 $\operatorname{par} C$ 유전자에 sense mutations을 가지고 있는 47 균주 중 44균주가 A. baumannii 였고3균주는 A. pittii 였다. 본 연구에서 조사대상이 되었던 Acb complex 균주들 중 plasmid-mediated quinolone resistance (PMQR) determinants를 가지고 있는 균주는 한나도 없었다. 46 균주의 ciprofloxacin 내성 $A$. baumannii 는 $\mathrm{A}, \mathrm{B}$, 또는 F형의 banding pattern을 보였는데 이는 충청지역에 위치한 일개의 병원에 ciprofloxacin 내성 A. baumanni가 수평확산 되어 있 음을 의미한다. Fluoroquinolone 내성 Acb complex 균주의 집락화 및 확산을 막기 위해서 다제내성 균주들을 대상으로 항 균제 내성인자들을 지속적으로 조사하고 모니터링할 필요가 있 을 것으로 사료된다.

Acknowledgements: This work was supported by the 2017 Far East University Research Grant (FEU2017R02).

Funding: None

Conflict of interest: None

\section{REFERENCES}

1. Sung JY. Clonal dissemination of multidrug resistant Acinetobacter baumannii isolates harboring blaoxa-23 at One University Hospital in Daejeon, Korea. Korean J Clin Lab Sci. 2016;48(2):94-101.

2. La Scola B, Gundi VA, Khamis A, Raoult D. Sequencing of the $r p o B$ gene and flanking spacers for molecular identification of Acinetobacter species. J Clin Microbiol. 2006;44(3):827-832.

3. Srinivasan VB, Rajamohan G, Pancholi P, Stevenson K, Tadesse $\mathrm{D}$, Patchanee P, et al. Genetic relatedness and molecular characterization of multidrug resistant Acinetobacter baumannii isolated in central Ohio, USA. Ann Clin Microbiol Antimicrob. 2009;8:21-22.

4. Vila J, Ruiz J, Goni P, Jimenez de Anta T. Quinolone-resistance mutations in the topoisomerase IV parC gene of Acinetobacter baumannii. J Antimicrob Chemother. 1997;39(6):757-762.

5. Jacoby GA. Mechanisms of resistance to quinolones. Clin Infect Dis. 2005; 41(Suppl 2):120-126.

6. Nordmann P, Poirel L. Emergence of plasmid-mediated resistance to quinolones in Enterobacteriaceae. J Antimicrob Chemother. 2005;56(3):463-469.

7. Jiang X, Yu T, Jiang X, Zhang W, Zhang L, Ma J. Emergence of plasmid-mediated quinolone resistance genes in clinical isolates of Acinetobacter baumannii and Pseudomonas aeruginosa in Henan, China. Diagn Microbiol Infect Dis. 2014;79(3):381383.

8. Touati A, Brasme L, Benallaoua S, Gharout A, Madoux J, De Champs C. First report of qnrB-producing Enterobacter cloacae and $q n r A$-producing Acinetobacter baumannii recovered 
from Algerian hospitals. Diagn Microbiol Infect Dis. 2008; 60(3):287-290.

9. Lim J, Lee G, Choi Y, Kim J. An analysis of the antibiotic resistance genes of multi-drug resistant (MDR) Acinetobacter baumannii. Korean J Clin Lab Sci. 2016;48(3):217-224.

10. Bou G, Cerveró G, Domínguez MA, Quereda C, MartínezBeltrán J. PCR-based DNA fingerprinting (REP-PCR, AP-PCR) and pulsed-field gel electrophoresis characterization of a nosocomial outbreak caused by imipenem- and meropenem-resistant Acinetobacter baumannii. Clin Microbiol Infect. 2000; 6(12):635-643.

11. CLSI. Performance Standards for Antimicrobial Susceptibility Testing; Sixteenth Informational Supplement. CLSI document M100-S20. Wayne, Pennsylvania: Clinical and Laboratory Standards Institute; 2010, p52-53.

12. Valentine SC, Contreras D, Tan S, Real LJ, Chu S, Xu HH. Phenotypic and molecular characterization of Acinetobacter baumannii clinical isolates from nosocomial outbreaks in Los Angeles County, California. J Clin Microbiol. 2008;46(8): 2499-2507.

13. Cattoir V, Poirel L, Rdotimi V, Soussy CJ, Nordmann P. Multiplex PCR for detection of plasmid-mediated quinolone resistance qnr genes in ESBL-producing enterobacterial isolates. J Antimicrob Chemother. 2007;60(2):394-397.

14. Park CH, Robicsek A, Jacoby GA, Sahm D, Hooper DC. Prevalence in the United States of aac(6)-Ib-cr encoding a ciprofloxacin-modifying enzyme. Antimicrob Agents Chemother. 2006;50(11):3953-3955.

15. Li J, Wang T, Shao B, Shen J, Wang S, Wu Y. Plasmid-mediated quinolone resistance genes and antibiotic residues in wastewater and soil adjacent to swine feedlots: potential transfer to agricultural lands. Environ Health Perspect. 2012;120(8):11441149.

16. Khorsi K, Messai Y, Hamidi M, Ammari H, Bakour R. High prevalence of multidrug-resistance in Acinetobacter baumannii and dissemination of carbapenemase-encoding genes blaoxA-23-lik,
blaoxA-24-like and bla NDM-1 $_{1}$ in Algiers hospitals. Asian Pac J Trop Med. 2015;8(6):438-446.

17. Park YK, Jung SI, Park KH, Kim DH, Choi JY, Kim SH, et al. Changes in antimicrobial susceptibility and major clones of Acinetobacter calcoaceticus-baumannii complex isolates from a single hospital in Korea over 7 years. J Med Microbiol. 2012;61(Pt 1):71-79.

18. Koo SH, Kwon KC, Cho HH, Sung JY. Genetic basis of multidrug-resistant Acinetobacter baumannii clinical isolates from three university hospitals in Chungcheong province, Korea. Korean J Lab Med. 2010;30(5):501-506.

19. Valentine SC, Contreras D, Tan S, Real LJ, Chu S, Xu HH. Phenotypic and molecular characterization of Acinetobacter baumannii clinical isolates from nosocomial outbreaks in Los Angeles County, California. J Clin Microbiol. 2008;46(8):24992507.

20. Güler G, Eraç B. Investigation of fluoroquinolone resistance mechanisms in clinical Acinetobacter baumannii isolates. Mikrobiyol Bul. 2016;50(2):278-286.

21. Lee JK, Lee YS, Park YK, Kim BS. Mutations in the gyrA and parC genes in ciprofloxacin-resistant clinical isolates of Acinetobacter baumannii in Korea. Microbiol Immunol. 2005; 49(7):647-653.

22. Yang H, Hu L, Liu Y, Ye Y, Li J. Detection of the plasmid-mediated quinolone resistance determinants in clinical isolates of Acinetobacter baumannii in China. J Chemother. 2016;28(5): 443-445.

23. Gu DX, Hu YJ, Zhou HW, Zhang R, Chen GX. Substitutions of Ser83Leu in GyrA and Ser80Leu in ParC Associated with Quinolone Resistance in Acinetobacter pittii. Microb Drug Resist. 2015;21(3):345-351.

24. MJ Jiang, Sh P Zhao, J M Li, FS Zhang. Molecular epidemiological study and detection of multi-drug resistant Acinetobacter baumannii -related resistance genes. African J Mirobiol Reser. 2013;7(48):5496-5502. 